\title{
Model Prediksi Financial Distress Grup Perusahaan Keluarga di Indonesia Dengan Model Beneish Ratio Index
}

\author{
Nurina Prawinin Tyas ${ }^{1}$, Nurmala Ahmar ${ }^{2}$, M. Ardiansyah Syam ${ }^{3}$ \\ 1,2, Universitas Pancasila, Jakarta, Indonesia
}

\section{INFO ARTIKEL \\ JEL Classification :}

G32, M41

Keywords :

financial distress, beneish m-score

\begin{abstract}
This study aims to test and prove the empirical evidence of the Financial Distress Prediction Model of Family Companies in Indonesia with the Beneish Ratio Index. The sample used in this study is a group of family companies in Indonesia which are listed on the Indonesia Stock Exchange with an observation period of 31 December 2014 to 2018. The research method used is a quantitative method with a survey approach for secondary data. The Days Sales in Receivable Index (DSRI), Sales Growth Index (SGI), Sales General and Administrative Index (SGAI), and Leverage Index (LVGI) variables do not differ in the treatment of the Beneish Model components based on the Financial Distress status of the Family Group Company. Variable Gross Margin Index (GMI), Asset Quality Index (AQI), Depreciation Index (DEPI), and Total Accruals to Total Assets Index (TATA) differ in the treatment of the Beneish Model component based on the Financial Distress status of the Family Company Group. This research contributes to the parties concerned with the prediction of financial distress, such as auditors and the government in assessing the potential for financial distress in the company.
\end{abstract}

\begin{abstract}
ABSTRAK
Studi ini bertujuan untuk menguji dan membuktikan bukti empiris Model Prediksi Financial Distress Grup Perusahaan Keluarga Di Indonesia Dengan Beneish Ratio Index. Sampel yang digunakan dalam penelitian ini adalah Grup perusahaan keluarga di Indonesia yang terdaftar di Bursa Efek Indonesia dengan periode pengamatan 31 Desember 2014 hingga 2018. Metode penelitian yang digunakan adalah metode kuantitatif dengan pendekatan survey untuk data sekunder. Variabel Days Sales in Receivable Index (DSRI), Sales Growth Index (SGI), Sales General and Administrative Index (SGAI), dan Leverage Index (LVGI) tidak ada perbedaan perlakuan komponen Beneish Model berdasarkan status Financial Distress pada Grup Perusahaan Keluarga. Variabel Gross Margin Index (GMI), Asset Quality Index (AQI), Depreciation Index (DEPI), dan Total Accruals to Total Assets Index (TATA) ada perbedaan perlakuan komponen Beneish Model berdasarkan status financial distress pada Grup Perusahaan Keluarga. Riset ini memberikan panduan kepada pihak-pihak yang berkepentingan terhadap memprediksi financial distress yang akan terjadi dalam perusahaan ataupun industri, pihak yang berkepentingan seperti Auditor dan Pemerintahan.
\end{abstract}




\section{Pendahuluan}

Perkembangan ekonomi yang semakin pesat dalam persaingan usaha semakin kompetitif yang mengharuskan perusahaan tetap mampu bersaing dalam bisnisnya bergerak dalam berbagai sektor. Disegala situasi kondisi, perusahaan memerlukan suatu keputusan yang tepat menyangkut upaya pengembangan usaha. Menurut data Indonesian Institute for Corporate and Directorship (IICD, 2010), lebih dari 95 persen bisnis di Indonesia merupakan perusahaan yang dimiliki maupun dikendalikan oleh keluarga. Artinya kegiatan bisnis keluarga terus memperlihatkan eksistensinya dengan memberikan kontribusi besar dalam menopang dan memberikan modal kekuatan terhadap pembangunan ekonomi nasional. Terutama, di saat krisis ekonomi pada tahun 1997/1998 serta 2008 pada pemulihan ekonomi nasional. Namun, bisnis keluarga tentu memiliki ragam persoalan yang kadang sulit dipecahkan (Simanjuntak, 2010).

Kesehatan perusahaan dapat dilihat dari hasil kinerja manajemen dalam mengelola dana dan bekerjasama dengan area usaha perusahaan yang merupakan faktor-faktor dari luar yang dapat mempengaruhi kinerja perusahaan baik organisasi maupun manajemennya (Anggarini, 2010).

Krisis keuangan disebabkan oleh perusahaan selalu rugi, penjualan tidak laku, musibah alam berakibat properti perusahaan rusak, sistem tata kelola (Corporate Governance) yang buruk dan keadaan perekonomian negeri tidak stabil yang mengakibatkan terjadi krisis keuangan secara meluas. Akibat terburuk yang muncul dari krisis keuangan yang dialami perusahaan adalah perusahaan dapat dinyatakan pailit/bangkrut oleh pengadilan di negara setempat. Tahap penurunan kondisi keuangan perusahaan yang terjadi sebelum terjadi kebangkrutan ataupun likuidasi disebut sebagai financial distress (Agusti, 2013).

Selain itu, menurut Brigham dan Daves dalam Hidayat (2013), financial distress terjalin atas serangkaian kesalahan, pengambilan keputusan yang tidak tepat serta kelemahan-kelemahan yang berhubungan berakibat secara langsung atau tidak langsung kepada manajemen dan minimnya upaya pengawasan keuangan perusahaan sehingga tidak cocok dengan apa yang diperlukan ( Hidayat, 2013). Oleh sebab itu dibutuhkan upaya menghindari perusahaan terjebak pada keadaan financial distress dengan memprediksi financial distress pada perusahaan. Dengan mengenali sedini mungkin kondisi financial distress pada perusahaan sehingga bisa mengambil tindakan apabila perusahaan menuju pada kebangkrutan (Hidayat, 2013).

Adapun contoh perusahaan yang mengalami financial Distress yaitu PT Modern Internasional Tbk (MDRN) per 30 Juni 2017 terjadi kebangkrutan pada anak usaha yaitu PT Modern Sevel Indonesia menutup gerai 7-Eleven (Sevel), penyebabnya karena besarnya pengeluaran biaya operasional, biaya sewa dan biaya infrastruktur sarana mengakibatkan hutang besar yang tidak mampu dibayarkan.

Kemudian Perusahaan Kodak yang bangkrut di tahun 2012 yaitu perusahaan pertama yang menemukan film gulung dan fotografi, dikarenakan tidak berinovasi dan bertahan dengan kamera sederhananya. Sementara perusahaan kamera lainnya melakukan inovasi dengan menciptakan kamera digital sesuai mengikuti perkembangan zaman dan permintaan pasar.

Lalu PT Sariwangi yang mengalami Distress disebabkan gagal bayar hutang dengan total 1,5 triliun kepada sejumlah bank yang dipakai untuk megembangkan teknologi air tetapi hasilnya tidak sesuai harapan sehingga tidak mampu membayar cicilan pinjaman Bank. Dan adapula Nyonya Meneer yang mengalami Distress disebabkan tidak mampu membayar hutang sebesar 267 miliar kepada sejumlah kreditur yang disebabkan krisis operasional yang panjang dan urusan internal perusahaan (sengketa perbutan kekuasaan antar Keluarga).

Salah satu yang mempengaruhi financial distress merupakan financial ratios, dimana dapat diamati di dalam informasi keuangan yang dirilis oleh perusahaan. Biasanya riset mengenai kebangkrutan, kecurangan, ataupun financial distress memakai kemampuan finansial sebagai memprediksi financial distress di Perusahaan yang akan datang. Indikatornya didapat dari penghitungan rasio-rasio keuangan yang ada pada data informasi finansial yang dikeluarkan perusahaan setiap triwulan maupun tahunan. (Hidayat, 2013).

Indikator yang digunakan untuk memprediksi financial distress adalah Beneish Ratio Index. Faktor-faktor Rasio Beneish yang digunakan untuk memprediksi financial distress ialah Days Sales Receivable Index (DSRI), Gross Margin Index (GMI), Asset Quality Index (AQI), Sales Growth Index (SGI), Depreciation Index (DEPI), Sales General and Administrative Index (SGAI), Leverage Index (LVGI) dan Total Accruals to Total Assets Index (TATA). 
Fenomena penelitian ini dipilih dikarenakan sedikitnya penelitian mengenai financial distress terhadap perusahaan keluarga di Indonesia yang terdaftar di BEI. Beberapa peneliti terdahulu melakukan penelitian terhadap financial distress di perusahaan manufaktur, jasa dan pertambangan yang terdaftar di BEI. Adapun peneliti terdahulu yang dilakukan oleh Kristanti dkk (2015) menyatakan "pengaruh rasio tata kelola perusahaan dan keuangan terhadap kemungkinan perusahaan keluarga Indonesia yang mengalami financial distress, ada perbedaan kinerja antara perusahaan keluarga dan perusahaan non keluarga Indonesia, namun tidak ada perbedaan risiko antara keduanya. Regresi logistik menunjukkan bahwa penerapan tata kelola perusahaan dapat meningkatkan kinerja keuangan perusahaan dan memungkinkan mereka untuk menghindari tekanan keuangan. Penelitian ini juga menunjukkan bahwa struktur modal konservatif tidak diadopsi oleh perusahaan keluarga Indonesia."

Banyak perusahaan yang didirikan oleh orangorang yang masih memiliki ikatan atau di sebut keluarga. Perusahaan keluarga berperan dalam mengelola dan mengendalikan seluruh kegiatan perusahaan baik dalam aturan, kewenangan dan kebijakan. Dalam dunia bisnis, perusahaan keluarga mampu bersaing dalam go publik dengan perusahaan-perusahaan disektor-sektor lain dalam go publik. Perusahaan Keluarga dapat mampu mempengaruhi kesejahteraan masyarakat dalam memberikan keinginan masyarakat karena berhubungan dengan kelangsungan umur perusahaan dalam persaingan bisnis. Banyak topik yang sering dibahas "apakah perusahaan keluarga memiliki kinerja lebih baik daripada perusahaan non keluarga, sehingga tidak mengalami Financial Distress?"

Berdasarkan latar belakang tersebut maka dilakukan prediksi faktor penjelas financial distress pada perusahaan keluarga di Indonesia pada Bursa Efek Indonesia. Grup Perusahaan keluarga dipilih sebagai objek penelitian karena perusahaan keluarga menunjukkan eksistensinya sebagai penopang sekaligus sebagai modal kekuatan dalam pemulihan ekonomi nasional. Periode objek penelitian adalah pada tahun 2015 sampai dengan 2018. Penelitian ini kemudian mengambil judul "Model Prediksi Financial distress Grup Perusahaan Keluarga di Indonesia Dengan Beneish Ratio Index".

\section{Telaah Teori Dan Pengembangan Hipotesis}

2.1. Perbedaan Days Sales in Receivable Index (DSRI) berdasrkan status financial distress
DSRI merupakan perbandingan dari pemasaran setiap hari dalam wujud piutang pada sesuatu tahun (t) dengan tahun lalu (t-1). Di Perusahaan, piutang dianggap bagus bila piutang itu besar yang melihatkan kalau kemampuan Perusahaan itu bagus sehingga terdapat adanya pengaruh variabel DSRI terhadap financial distress (Kusuma, 2017). Berdasarkan uraian tersebut, maka hipotesis pertama dalam penelitian ini adalah sebagai berikut:

$\mathrm{H}_{1}$ : Days Sales Receivable Index (DSRI) ada perbedaan berdasarkan status financial distress.

\subsection{Perbedaan Gross Margin Index (GMI) berdasarkan status financial distress}

Perbandingan GMI dipakai membuktikan seberapa besar persentase pemasukan bersih yang diperoleh dari pemasaran. Bila GMI pada tahun terpaut lebih kecil pada tahun lalu akan membawa alamat kalau peluang perusahaan memburuk, alhasil perusahaan lebih bisa melaksanakan permainan dalam laporan (Kusuma, 2017). Berdasarkan uraian tersebut, maka hipotesis kedua dalam penelitian ini adalah sebagai berikut:

$\mathrm{H}_{2}$ : Gross Margin Index (GMI) ada perbedaan berdasrkan status financial distress.

\subsection{Perbedaan asset Quality Index berdasarkan status financial distress}

(AQI)

AQI untuk mengukur mutu aset perusahaan dengan mengukur perbandingan aset tetap, aset tetap Property, Plant and Equipment (PPE) dengan total asset. Perusahaan yang memalsukan asetnya dalam penyajian aset, dapat dicoba dengan metode meningkatkan angka aset serta mengurangi kewajiban supaya earning power jadi lebih besar serta posisi finansial lebih kuat (Kusuma, 2017). Berdasarkan uraian tersebut, maka hipotesis ketiga dalam penelitian ini adalah sebagai berikut:

$\mathrm{H}_{3}$ : Asset Quality Index (AQI) ada perbedaan berdasarkan status financial distress.

\subsection{Perbedaan Sales Growth Index berdasarkan status financial distress}

(SGI)

SGI merupakan perbandingan pemasaran pada sesuatu tahun (t) dengan tahun lalu (t-1). Bila hasilnya lebih besar dari 1 didindikasi pemasaran bertambah dari tahun sebelumnya. Hal tersebut dapat membuat industri hadapi perkembangan dibawah rata-rata, pada umumnya administrator dapat memalsukan informasi. Berdasarkan uraian tersebut, maka hipotesis keempat dalam penelitian ini adalah sebagai berikut: 
$\mathrm{H}_{4}$ : Sales Growth Index (SGI) ada perbedaan berdasarkan status financial distress

\subsection{Perbedaan Depreciation Index berdasarkan status financial distress}

(DEPI)

DEPI ialah perbandingan rasio beban depresiasi pada aktiva tetap sebelum depresiasi tahun ( $t$ ) serta tahun lalu (t-1). Bila DEPI lebih dari 1 indikasi kalau aset sudah disusutkan dan tingkatkan mungkin kalau perusahaan melakukan revisi laporan. Pada kalkulasi depresiasi menggunakan metode kayak garis lurus serta angka tahun (Kusuma, 2017). Berdasarkan uraian tersebut, maka hipotesis kelima dalam penelitian ini adalah sebagai berikut:

$\mathrm{H}_{5}$ : Depreciation Index (DEPI) ada perbedaan berdasarkan status financial distress.

\subsection{Perbedaan Sales General and Administrative Index (SGAI) berdasarkan status financial distress}

SGAI merupakan perbandingan beban penjualan, umum, dan administrasi dengan penjualan pada tahun $(\mathrm{t})$ dengan tahun lalu $(\mathrm{t}-1)$. Ketika perusahaan tidak dapat mempertahankan aktivitas penjualan, maka dapat dilakukan Distress dengan cara memanfaatkan aset perusahaan untuk menghasilkan pendapatan (Hantono, 2018). Berdasarkan uraian tersebut, maka hipotesis keenam dalam penelitian ini adalah sebagai berikut:

$\mathrm{H}_{6}$ : Sales General and Administrative Index (SGA) ada perbedaan berdasarkan status financial distress.

\subsection{Perbedaan Leverage Index (LVGI) berdasarkan status financial distress}

LVGI ialah perbandingan jumlah hutang kepada keseluruhan aktiva di tahun $(\mathrm{t})$ dengan tahun lalu ( $\mathrm{t}$ 1). LVGI membuktikan kemampuan melunasi kewajiban yang dimiliki. Bila LVGI lebih dari 1 diindikasi naiknya leverage dan perusahaan lebih rentan terjadi manipulasi pendapatan. Berdasarkan uraian tersebut, maka hipotesis ketujuh dalam penelitian ini adalah sebagai berikut:

$\mathrm{H}_{7}$ : Sales General and Administrative Index (SGA) ada perbedaan berdasarkan status financial distress.

\subsection{Perbedaan Total Accruals to Total Assets Index (TATA) berdasarkan status financial distress}

TATA ialah perbandingan spekulasi sejauh mana cash melandasi pemasukan yang dilaporkan, serta berspekulasi accruals positif yang lebih besar dihubungkan dengan kemungkinan manipulasi pemasukan yang lebih besar. Semakin tinggi total aset perusahaan dapat menilai perusahaan tersebut memiliki kekayaan yang tinggi. Berdasarkan uraian tersebut, maka hipotesis kedelapan dalam penelitian ini adalah sebagai berikut:

$\mathrm{H}_{8}$ : Total Accruals to Total Assets Index (TATA) ada perbedaan berdasarkan status financial distress.

\section{METODE PENELITIAN}

Penelitian ini merupakan penelitian metode kuantitatif dan tergolong penelitian riset kausal. Populasi dalam penelitian ini adalah seluruh perusahaan keluarga yang terdaftar di Bursa Efek Indonesia dengan periode pengamatan tahun 2015 hingga 2018. Dalam penelitian ini menggunakan tehnik pengambilan sampel yang dilakukan secara purposive sampling dengan tujuan untuk mendapatkan sampel yang sesuai dengan kriteria yang diinginkan peneliti. Adapun sampel yang digunakan dengan 4 nama grup terdiri dari 36 perusahaan yang memenuhi kriteria sebagai sampel. Data yang digunakan dalam penelitian ini adalah data sekunder berupa laporan keuangan diperoleh dari Bursa Efek Indonesia yaitu www.idx.co.id dan data dokumen di ICMD (Indonesia Capital Market Directory). Penelitian ini menggunakan Analisis logistic regresion dengan menggunakan program Statistical Packagefor Sosial Sciens (SPSS).

Persamaan model logistic regresion yang digunakan adalah sebagai berikut:

Financial distress $(\mathrm{Y})=\beta 0+\beta 1 \mathrm{DSRI}+\beta 2 \mathrm{GMI}+$ $\beta 3 \mathrm{AQI}+\beta 4 \mathrm{SGI}+\beta 5 \mathrm{DEPI}+\beta 6 \mathrm{SGAI}+\beta 7 \mathrm{TATA}$ $+\beta 8 \mathrm{LVGI}+\varepsilon \mathrm{i}$

Keterangan :

Financial distress : variabel dummy $\beta 1, \beta 2, \beta 3, \beta 4, \beta 5, \beta 6, \beta 7, \beta 8$ : Koefisien regresi

DSRI : Day's sales receivables index

GMI : Gross profit margin

AQI : Asset quality index

SGI : Sales growth index

DEPI : Depreciation index

SGAI : Sales and general administration expenses index

LVGI : Leverage index

TATA : Total Assets

ci : Residual

\section{Hasil Penelitian dan Pembahasan}

\subsection{Analisis Deskriptif Variabel secara keseluruhan}

Perbedaan jumlah sampel tiap Grup Perusahaan Keluarga dikarenakan terdapat perusahaan pada 
tahun tertentu tidak bisa memberikan laporan keuangan tahunan secara baik sehingga tidak dapat diolah dengan rumus 8 komponen Model Beneish. Berikut hasil analisis deskripsi sebagai berikut:

Tabel 4

Descriptive Statistics

\begin{tabular}{|c|c|c|c|c|c|}
\hline & $\mathrm{N}$ & Mean & $\begin{array}{c}\text { Std. } \\
\text { Deviation }\end{array}$ & Minimum & Maximum \\
\hline DSRI & 132 & 1,29549 & 1,789185 & 000 & 19,255 \\
\hline GMI & 132 & 1,15055 & 980024 & ,239 & 9,039 \\
\hline AOI & 132 & 1,10519 & 374006 &, 304 & 3,289 \\
\hline SGI & 132 & 1,57304 & 5,505437 &, 046 & 64,020 \\
\hline DEPI & 132 & 1,06142 & 362688 & 170 & 3,403 \\
\hline SGAI & 132 & 1,11651 & 1,285428 &, 053 & 15,549 \\
\hline LVGI & 132 & 1,52667 & 4,036007 &, 385 & 43,883 \\
\hline TATA & 132 & 52067 & 481578 & 004 & 2,277 \\
\hline
\end{tabular}

Dari hasil tabel diatas dapat diketahui bahwa variabel Days Sales in Receivable Index (DSRI) memiliki nilai minimum 0,00 dan maksimum 19,26 dengan nilai rata-ratanya sebesar 1,295 yang menunjukkan secara keseluruhan DSRI memiliki nilai baik untuk dapat menjelaskan teori ada perbedaan berdasarkan status financial distress yaitu diatas satu dan standar deviasinya (tingkat sebaran data) sebesar 1,79 menunjukkan bahwa nilai DSRI yang digunakan memiliki kecenderungan data yang beragam.

Variabel Gross Margin Index (GMI) memiliki nilai terendah 0,24 dan nilai tertingginya 9,04 dengan nilai rata-ratanya sebesar 1,150 yang menunjukkan secara keseluruhan GMI memiliki nilai baik untuk menjelaskan teori ada perbedaan berdasarkan status financial distress yaitu diatas satu dan tingkat sebaran datanya 0,98 menunjukkan bahwa nilai GMI yang digunakan memiliki kecenderungan data yang sedikit beragam.

Variabel Asset Quality Index (AQI) memiliki nilai terendah sebesar 0,30 dan nilai tertinggi sebesar 3,29 dengan nilai rata-ratanya 1,11 menunjukkan secara keseluruhan AQI memiliki nilai baik untuk menjelaskan teori ada perbedaan berdasarkan status financial distress yaitu diatas satu dan tingkat sebaran datanya sebesar 0,37 menunjukkan bahwa nilai $\mathrm{AQI}$ yang digunakan memiliki kecenderungan data yang tidak beragam.

Variabel Sales Growth Index (SGI) memiliki nilai terendah 0,05 dan nilai tertinggi sebesar 64,02 dengan nilai rata-rata sebesar 1,57 menunjukkan secara keseluruhan SGI memiliki nilai baik untuk menjelaskan teori ada perbedaan berdasarkan status financial distress yaitu diatas satu dan tingkat sebaran data sebesar 5,51 menunjukkan bahwa nilai SGI yang digunakan memiliki kecenderungan data yang beragam.

Variabel Depreciation Index (DEPI) memiliki nilai terendah 0,17 dan nilai tertinggi sebesar 3,40 dengan nilai rata-rata sebesar 1,06 menunjukkan secara keseluruhan DEPI memiliki nilai baik untuk menjelaskan teori ada perbedaan berdasarkan status financial distress yaitu diatas satu dan tingkat sebaran data sebesar 0,36 menunjukkan bahwa nilai DEPI yang digunakan memiliki kecenderungan data yang tidak beragam.

Variabel Sales, General and Administrative Expenses Index (SGAI) memiliki nilai terendah sebesar 0,05 dan nilai tertinggi sebesar 15,55 dengan nilai rata-rata sebesar 1,12 menunjukkan secara keseluruhan SGAI memiliki nilai baik untuk menjelaskan teori ada perbedaan berdasarkan status financial distress yaitu diatas satu dan tingkat sebaran data sebesar 1,29 menunjukkan bahwa nilai SGAI yang digunakan memiliki kecenderungan data yang sedikit sama.

Variabel Leverage Index (LVGI) memiliki nilai terendah sebesar 0,39 dan nilai tertinggi sebesar 43,88 dengan nilai rata-rata sebesar 1,53 menunjukkan secara keseluruhan LVGI memiliki nilai baik untuk menjelaskan teori ada perbedaan berdasarkan status financial distress yaitu diatas satu dan tingkat sebaran data sebesar 4,04 menunjukkan bahwa nilai LVGI yang digunakan memiliki kecenderungan data yang beragam.

Variabel Total Accruals to Total Assets (TATA) memiliki nilai terendah sebesar 0,00 dan nilai tertinggi sebesar 2,28 dengan nilai rata-rata sebesar 0,52 menunjukkan secara keseluruhan TATA memiliki nilai baik untuk menjelaskan teori ada perbedaan berdasarkan status financial distress yaitu diatas $50 \%$ dan tingkat sebaran data sebesar 0,48 menunjukkan bahwa nilai TATA yang digunakan memiliki kecenderungan data yang tidak beragam. 


\subsection{Deskripsi Variabel berdasarkan Status Financial Distress}

Tabel 5 Deskripsi Variabel Status Financial Distress
GRUP_KOD * FINANCIAL DISTRESS Crosstabulation
\begin{tabular}{|ll|r|r|r|}
\hline \multirow{2}{*}{ Count } & & \multicolumn{2}{c|}{ FINANCIAL DISTRESS } & \\
\cline { 3 - 4 } & & TIDAK & TISTRESS & \multicolumn{2}{|c|}{ Total } \\
\hline GRUP_KOD & BAKRIE & 8 & 23 & 31 \\
& LIPPO & 0 & 36 & 36 \\
& SALIM & 0 & 32 & 32 \\
& SINARMAS & 3 & 30 & 33 \\
Total & 11 & 121 & 132 \\
\hline
\end{tabular}

Tabel 6, Deskripsi 8 komponen berdasarkan Status Financial Distress Group Statistics

\begin{tabular}{|l|l|r|r|r|c|}
\hline & FINANCIAL & $\mathrm{N}$ & Mean & $\begin{array}{c}\text { Std. } \\
\text { Deviation }\end{array}$ & $\begin{array}{c}\text { Std. Error } \\
\text { Mean }\end{array}$ \\
\hline DISTRESS & DISTRESS & 121 & 1,36292 & 1,850901 &, 168264 \\
& TIDAK DISTRESS & 11 &, 55377 &, 406604 &, 122596 \\
\hline GMI & DISTRESS & 121 & 1,16712 & 1,022054 &, 092914 \\
& TIDAK DISTRESS & 11 &, 96832 &, 082947 &, 025009 \\
\hline AOI & DISTRESS & 121 & 1,10501 &, 370549 &, 033686 \\
& TIDAK DISTRESS & 11 & 1,10719 &, 429830 &, 129599 \\
\hline SGI & DISTRESS & 121 & 1,64825 & 5,745343 &, 522304 \\
& TIDAK DISTRESS & 11 &, 74573 &, 360452 &, 108680 \\
\hline DEPI & DISTRESS & 121 & 1,06713 &, 365054 &, 033187 \\
& TIDAK DISTRESS & 11 &, 99862 &, 345406 &, 104144 \\
\hline SGAI & DISTRESS & 121 & 1,11137 & 1,326134 &, 120558 \\
& TIDAK DISTRESS & 11 & 1,17304 &, 733504 &, 221160 \\
\hline LVGI & DISTRESS & 121 & 1,54293 & 4,208151 &, 382559 \\
& TIDAK DISTRESS & 11 & 1,34784 &, 921805 &, 277935 \\
\hline TATA & DISTRESS & 121 &, 55876 &, 484704 &, 044064 \\
& TIDAK DISTRESS & 11 &, 10158 &, 089991 &, 027133 \\
\hline
\end{tabular}

Berdasarkan tabel diatas hasil deskripsi Group Statistics diatas diketahui bahwa tiap komponen variabel memiliki jumlah status financial distress yang sama yaitu untuk kelompok "Distress" sebesar 121 perusahaan pada tahun tertentu dan kelompok "Tidak Distress" sebesar 11 perusahaan dengan tahun tertentu.

Adapun rincian deskripsi 8 komponen berdasarkan Status Financial Distress adalah Variabel Days Sales in Receivable Index (DSRI) berdasarkan financial distress memiliki nilai ratarata Distress 1,363 dan nilai rata-rata Tidak Distress 0,554, maka disimpulkan ada perbedaan status financial distress. Variabel Gross Margin Index
(GMI) berdasarkan financial distress memiliki nilai rata-rata Distress 1,167 dan nilai rata-rata Tidak Distress 0,968, maka disimpulkan ada perbedaan status financial distress. Variabel Asset Quality Index (AQI) berdasarkan financial distress memiliki nilai rata-rata Distress 1,105 dan nilai rata-rata Tidak Distress 1,107, maka disimpulkan ada perbedaan status financial distress. Variabel Sales Growth Index (SGI) berdasarkan financial distress memiliki nilai rata-rata Distress 1,648 dan nilai rata-rata Tidak Distress 0,746 , maka disimpulkan ada perbedaan status financial distress. Variabel Depreciation Index (DEPI) berdasarkan financial distress memiliki nilai rata-rata Distress 1,067 dan nilai rata- 
rata Tidak Distress 0,999, maka disimpulkan ada perbedaan status financial distress. Variabel Sales, General and Administrative Expenses Index (SGAI) berdasarkan financial distress memiliki nilai ratarata Distress 1,111 dan nilai rata-rata Tidak Distress 1,173, maka disimpulkan ada perbedaan status financial distress. Variabel Leverage Index (LVGI) berdasarkan financial distress memiliki nilai ratarata Distress 1,543 dan nilai rata-rata Tidak Distress 1,348, maka disimpulkan ada perbedaan status financial distress. Variabel Total Accruals to Total Assets (TATA) berdasarkan financial distress memiliki nilai rata-rata Distress 0,559 dan nilai ratarata Tidak Distress 0,102, maka disimpulkan ada perbedaan status financial distress.

\subsection{Hasil Uji Hipotesis dengan Wald Test}

Uji signifikan atau uji parameter $\beta$ artinya menguji tingkat signifikan/pengujian parameter $\beta$. Pengujian yang dilakukan dalam penelitian ini yaitu secara parsial dan simultan dengan menggunakan Uji Wald (Wald Test). Setiap hubungan dalam atau antara tiap data dinyatakan sebagai model statistik dengan parameter $\beta$ yang diambil dari sampel uji. Uji Wald digunakan untuk menguji nilai sebenarnya parameter $\beta$ berdasarkan estimasi sampel. Hasil pengujian hipotesis disajikan pada tabel sebagai berikut:

Tabel 4.11 Hasil Pengujiann Hivotesis dengan Wald Test

\begin{tabular}{|c|c|c|c|c|c|c|}
\hline & & $B$ & S.E. & Wald & $d f$ & Sig. \\
\hline Step $1^{3}$ & DSRI & 101,006 & 4843,016 &, 000 & 1 & 983 \\
\hline & GMI & 41,370 & 4482,935 &, 000 & 1 & 993 \\
\hline & AQl & 73,425 & 2430,418 &, 001 & 1 & 976 \\
\hline & $S G \mid$ & 58,597 & 3862,601 &, 000 & 1 &, 988 \\
\hline & DEPI & 87,879 & 6134,507 &, 000 & 1 & 989 \\
\hline & SGAl & $-60,939$ & 4365,587 &, 000 & 1 & ,989 \\
\hline & LVGI & $-4,094$ & 417,402 &, 000 & 1 &, 992 \\
\hline & TATA & 651,799 & 13483,056 &, 002 & 1 & 961 \\
\hline & Constant & $.355,558$ & 14128,883 & .001 & 1 & 980 \\
\hline
\end{tabular}

Berdasarkan tabel diatas hasil pengujian secara Parsial sebagai berikut:

\section{a. Variabel Days Sales in Receivable Index (DSRI)}

Berdasarkan tabel 4.8 diatas dapat diketahui bahwa diperoleh nilai wald sebesar 0,000 (sig.0.983) nilai signifikansi 0,983 lebih besar dari 0,05 (5\%). Maka disimpulkan bahwa hipotesis ditolak yaitu variabel Days
Sales in Receivable Index (DSRI) tidak berpengaruh signifikan terhadap Financial Distress.

\section{b. Variabel Gross Margin Index (GMI)}

Berdasarkan tabel 4.8 dapat diartikan bahwa nilai wald sebesar 0,000 (sig.0.993). Nilai signifikansi 0,993 lebih besar dari 0,05 (5\%). Maka disimpulkan bahwa hipotesis ditolak yaitu variabel Gross Margin Index (GMI) tidak berpengaruh signifikan terhadap Financial Distress.

\section{c. Variabel Asset Quality Index (AQI)}

Berdasarkan tabel 4.8 dapat diartikan bahwa nilai wald sebesar 0,001 (sig.0.976). Nilai signifikansi 0,976 lebih besar dari 0,05 (5\%). Maka disimpulkan bahwa hipotesis ditolak yaitu variabel Asset Quality Index (AQI) tidak berpengaruh signifikan terhadap Financial Distress.

\section{d. Variabel Sales Growth Index (SGI)}

Berdasarkan tabel 4.8 dapat diartikan bahwa nilai wald sebesar 0,000 (sig.0.988). Nilai signifikansi 0,988 lebih besar dari 0,05 (5\%). Maka disimpulkan bahwa hipotesis ditolak yaitu variabel Sales Growth Index (SGI) tidak berpengaruh signifikan terhadap Financial Distress.

\section{e. Variabel Depreciation Index (DEPI)}

Berdasarkan tabel 4.8 dapat diartikan bahwa nilai wald sebesar 0,000 (sig.0.989). Nilai signifikansi 0,989 lebih besar dari 0,05 (5\%). Maka disimpulkan bahwa hipotesis ditolak yaitu variabel Depreciation Index (DEPI) tidak berpengaruh signifikan terhadap Financial Distress.

\section{f. Variabel Sales, General and Administrative Expenses Index (SGAI)}

Berdasarkan tabel 4.8 dapat diartikan bahwa nilai wald sebesar 0,000 (sig.0.989). Nilai signifikansi 0,989 lebih besar dari 0,05 (5\%). Maka disimpulkan bahwa hipotesis ditolak yaitu variabel Sales, General and Administrative Expenses Index (SGAI) tidak berpengaruh signifikan terhadap Financial Distress.

Variabel bertanda (-) menunjukkan bahwa semakin besar beban usaha yang dibebankan mengakibatkan perusahaan mengalami kerugian dikarenakan tidak dapat mempertahankan aktivitas penjualan/pendapatan maka perusahaan akan mengalami distress lebih tinggi dibanding perusahaan lain.

\section{g. Variabel Leverage Index (LVGI)}

Berdasarkan tabel 4.8 dapat diartikan bahwa nilai wald sebesar 0,000 (sig.0.992). Nilai signifikansi 0,992 lebih besar dari 0,05 (5\%). Maka disimpulkan bahwa 
hipotesis ditolak yaitu variabel Leverage Index (LVGI) tidak berpengaruh signifikan terhadap Financial Distress.

Variabel bertanda (-) menunjukkan bahwa semakin besar kewajiban yang harus dibayarkan mengakibatkan perusahaan mengalami kerugian dikarenakan tidak dapat melunasi kewajibannya/hutang maka perusahaan akan mengalami distress lebih tinggi dibanding perusahaan lain.

\section{h. Variabel Total Accruals to Total Assets (TATA)}

Berdasarkan tabel 4.8 dapat diartikan bahwa nilai wald sebesar 0,002 (sig.0.961). Nilai signifikansi 0,961 lebih besar dari 0,05 (5\%). Maka disimpulkan bahwa hipotesis ditolak yaitu variabel Total Accruals to Total Assets (TATA) tidak berpengaruh signifikan terhadap Financial Distress.

Dari hasil yang sudah dilakukan pengujian dengan uji Logistik didapat hasil yang kurang memuaskan dan tidak membuktikan teori, maka peneliti melakukan tambahan pengujian dengan Uji beda pada sampel berdasarkan status financial distress dan berdasarkan Grup Perusahaan Keluarga di BEI dengan menggunakan 8 komponen Model Beneish.

Tabel. 7 Hasil Uji Beda berdasarkan Grup Perusahaan Keluarga

ANOVA

\begin{tabular}{|c|c|c|c|c|c|c|}
\hline & & Sum of Squares & $d f$ & Mean Square & $\mathrm{F}$ & Sig. \\
\hline \multirow[t]{3}{*}{ DSRI } & Between Groups & 1,585 & 3 & \multirow{3}{*}{$\begin{array}{r}.528 \\
3,264\end{array}$} & \multirow[t]{3}{*}{, 162} & \multirow[t]{3}{*}{.822} \\
\hline & Within Groups & 417,770 & 128 & & & \\
\hline & Total & 418,355 & 131 & & & \\
\hline \multirow[t]{3}{*}{ GMI } & Between Groups & 8,609 & 3 & \multirow{3}{*}{$\begin{array}{r}2,890 \\
.815\end{array}$} & \multirow[t]{3}{*}{3,157} & \multirow[t]{3}{*}{.027} \\
\hline & Within Groups & 117,150 & 128 & & & \\
\hline & Total & 125,810 & 131 & & & \\
\hline \multirow[t]{3}{*}{$A Q \mid$} & Between Groups & 1,002 & 3 & \multirow{3}{*}{$\begin{array}{l}.334 \\
.135\end{array}$} & \multirow[t]{3}{*}{2,488} & \multirow[t]{3}{*}{.085} \\
\hline & Within Groups & 17,322 & 128 & & & \\
\hline & Total & 18,324 & 131 & & & \\
\hline \multirow[t]{3}{*}{ SGI } & Between Groups & 70,175 & 3 & \multirow{3}{*}{$\begin{array}{l}23,392 \\
30,472\end{array}$} & \multirow[t]{3}{*}{,788 } & \multirow[t]{3}{*}{.514} \\
\hline & Within Groups & 3800,414 & 128 & & & \\
\hline & Total & 3970,588 & 131 & & & \\
\hline \multirow[t]{3}{*}{ DEPI } & Between Groups & .848 & 3 & \multirow{3}{*}{$\begin{array}{l}.282 \\
, 128\end{array}$} & \multirow[t]{3}{*}{2,204} & \multirow[t]{3}{*}{.091} \\
\hline & Within Groups & 16,386 & 128 & & & \\
\hline & Total & 17,232 & 131 & & & \\
\hline \multirow[t]{3}{*}{ SGAI } & Between Groups & 6,526 & 3 & \multirow{3}{*}{$\begin{array}{l}2,175 \\
1,840\end{array}$} & \multirow[t]{3}{*}{1,328} & \multirow[t]{3}{*}{.268} \\
\hline & Within Groups & 209,829 & 128 & & & \\
\hline & Total & 216,454 & 131 & & & \\
\hline \multirow[t]{3}{*}{ LVGI } & Between Groups & 81,801 & 3 & \multirow{3}{*}{$\begin{array}{l}27,287 \\
16,032\end{array}$} & \multirow[t]{3}{*}{1,701} & \multirow[t]{3}{*}{.170} \\
\hline & Within Groups & 2052,103 & 128 & & & \\
\hline & Total & 2133,805 & 131 & & & \\
\hline \multirow[t]{3}{*}{ TATA } & Between Groups & 6,578 & 3 & \multirow{3}{*}{$\begin{array}{r}2,183 \\
, 188\end{array}$} & \multirow[t]{3}{*}{11,780} & \multirow[t]{3}{*}{.000} \\
\hline & Within Groups & 23,803 & 128 & & & \\
\hline & Total & 30,381 & 131 & & & \\
\hline
\end{tabular}

Sumber Data diolah
Berdasarkan tabel diatas dapat diketahui bahwa berdasarkan Grup Perusahaan Keluarga yang memiliki respon uji beda ada pada 4 komponen yaitu Gross Margin Index (GMI) dengan nilai signifikansi sebesar 0,027; komponen Asset Quality Index (AQI) dengan nilai signifikansi sebesar 0,065 ; komponen Depreciation Index (DEPI) dengan nilai signifikansi sebesar 0,091 dan komponen Total Accruals to Total Assets (TATA) dengan nilai signifikansi sebesar 0,000. Dari keempat komponen tersebut memiliki nilai signifikansi dibawah $0,10(10 \%)$ yang artinya memiliki respon ada perbedaan yang signifikansi berdasarkan Grup Perusahaan Keluarga daripada komponen lain terhadap status financial distress.

Hasil dari analisis diatas dapat dilakukan pembahasan sebagai berikut:

\section{Perbedaan Days Sales in Receivable Index (DSRI) berdasarkan status financial distress pada Grup Perusahaan Keluarga}

Hasil pengujian menggunakan uji beda menunjukkan bahwa komponen Days Sales in Receivable Index (DSRI) tidak ada perbedaan perlakuan atau tidak berpengaruh terhadap status Financial Distress berdasarkan Grup Perusahaan Keluarga. DSRI adalah rasio perbandingan antara penjualan harian dalam bentuk piutang pada tahun ini $(t)$ terhadadap tahun sebelumnya $(\mathrm{t}-1)$. Kenaikan penjualan harian dapat kemungkinan perusahaan membuat perubahan kebijakan kredit untuk mendorong percepatan penjualan dan memperoleh laba.

Hasil penelitian ini tidak sependapat dengan teori dasarnya Profesor Messod Beneish karena seharusnya Beneish M-Score adalah sebuah metode dalam membantu mengungkap perusahaan yang diindikasi melakukan distress terhadap pendapatan yang dicatat didalam laporan keuangan perusahaan. Namun, model ini hanya dapat memprediksi financial distress dari informasi laporan keuangan perusahaan public. Yang diartikan bahwa model tersebut tidak dapat digunakan untuk perusahaan private atau non-public. Keterbatasan lainnya yaitu manipulasi pendapatan hanya dapat dideteksi pada kelebihan saji daripada kekurangan saji. Jadi disimpulkan bahwa model tersebut tidak dapat digunakan untuk mempelajari perusahaan yang beroperasi dalam keadaan yang kondusif untuk penurunan laba (Christy \& Stephanus, 2018) namun didukung oleh penelitian yang dilakukan oleh Hantono, (2018) dan tidak didukung penelitian yang dilakukan oleh Kusuma, (2017).

2. Perbedaan Gross Margin Index (GMI) berdasarkan status financial distress pada Grup Perusahaan Keluarga 
Hasil pengujian menggunakan uji beda menunjukkan bahwa variabel Gross Margin Index (GMI) ada perbedaan perlakuan atau berpengaruh terhadap status financial distress berdasarkan Grup Perusahaan Keluarga. Komponen Gross Margin Index digunakan untuk menunjukkan sinyal terjadinya kelebihan pada laba, dan mengetahui prosentase pendapatan bersih dari penjualan. Apabila laba yang didapat pada tahun ini lebih kecil dari tahun sebelumnya, maka diindikasikan prospek perusahaan memburuk, sehingga dimungkinkan perusahaan melakukan manipulasi. Jika rasio GMI lebih dari nilai 1, maka laba kotor dari perusahaan menurun. Dapat berakibat manajemen perusahaan melakukan manipulasi dengan membuat angka yang lebih baik. Dengan semakin tinggi rasio laba, maka semakin diindikasi adanya manipulasi laporan keuangan dalam perusahaan.

Hasil penelitian ini sependapat dengan teori dasar Beneish M-Score yang dikembangkan oleh Profesor Messod Beneish bahwa Beneish M-Score adalah sebuah metode dalam membantu mengungkap kemungkinan adanya distress pada perusahaan terhadap pendapatan yang dicatat dalam laporan keuangan perusahaan (Christy \& Stephanus, 2018), dan didukung oleh penelitian yang dilakukan oleh Kusuma, (2017).

\section{Perbedaan Asset Quality Index (AQI) berdasarkan status financial distress pada Grup Perusahaan Keluarga}

Hasil pengujian menggunakan uji beda menunjukkan bahwa variabel Asset Quality Index (AQI) ada perbedaan perlakuan atau berpengaruh terhadap status Financial Distress berdasarkan Grup Perusahaan Keluarga. AQI menunjukkan adanya penurunan kualitas aset karena terjadinya peningkatan jumlah aset tidak lancar yang dapat mengakibatkan jumlah beban yang ditangguhkan. Hal itu untuk upaya meningkatkan laba bersih yang dapat diindikasi terjadinya distress karena dampak manipulasi data.

Hasil penelitian ini sependapat dengan teori dasar Beneish M-Score yang dikembangkan oleh Profesor Messod Beneish bahwa Beneish M-Score adalah sebuah metode membantu mengungkap kemungkinan distress pada perusahaan terhadap aset yang dicatat dalam laporan keuangan (Christy \& Stephanus, 2018), namun tidak didukung oleh penelitian yang dilakukan oleh Hantono, (2018).

\section{Perbedaan Sales Growth Index (SGI) berdasarkan status financial distress pada Grup Perusahaan Keluarga}

Hasil pengujian menggunakan uji beda menunjukkan bahwa variabel Sales Growth Index
(SGI) tidak ada perbedaan perlakuan atau tidak berpengaruh terhadap status Financial Distress berdasarkan Grup Perusahaan Keluarga. SGI adalah rasio yang digunakan untuk perbandingan dengan perhitungan penjualan tahun ini dari tahun lalu. Apabila penjualan meningkat dari tahun sebelumnya ke tahun ini, maka ada kenaikan laba. Apabila perusahaan menilai kenaikan laba adalah persepsi pertumbuhan perusahaan yang baik maka artinya dapat diindikasi akan terjadinya manipulasi penjualan yang dapat mengakibatkan peningkatan laba dari tahun ke tahun dan hal itu dapat terjadinya distress pada perusahaan.

Hasil penelitian ini tidak sependapat dengan teori dasar Beneish M-Score yang dikembangkan oleh Profesor Messod Beneish bahwa Beneish MScore adalah sebuah metode membantu mengungkap kemungkinan distress pada perusahaan terhadap penjualan yang dicatat dalam laporan keuangan perusahaan (Christy \& Stephanus, 2018), namun didukung oleh penelitian yang dilakukan oleh Hantono, (2018).

\section{Perbedaan Depreciation Index (DEPI) berdasarkan status financial distress pada Grup Perusahaan Keluarga}

Hasil pengujian menggunakan uji beda menunjukkan bahwa variabel Depreciation Index (DEPI) ada perbedaan perlakuan atau berpengaruh terhadap status Financial Distress berdasarkan Grup Perusahaan Keluarga. DEPI adalah rasio perhitungan fasilitas fisik perusahaan dalam bentuk biaya satu periode. Apabila menunjukkan penurunan beban penyusutan aset tetap yang mengakibatkan terjadinya peningkatan laba, maka diindikasi terjadinya manipulasi beban penyusutan aset tetap untuk memperoleh laba tiap tahun. Dalam penghitungan depresiasi sudah terdapat metode yang digunakan yaitu garis lurus dan angka tahun.

Hasil penelitian ini sependapat dengan teori dasar Beneish M-Score yang dikembangkan oleh Profesor Messod Beneish bahwa Beneish M-Score adalah sebuah metode membantu mengungkap kemungkinan distress pada perusahaan terhadap biaya-biaya yang dicatat dalam laporan keuangan perusahaan (Christy \& Stephanus, 2018) namun tidak didukung oleh penelitian yang dilakukan oleh Kusuma (2017) dan Hantono (2018).

6. Perbedaan Sales General and Administrative Index (SGAI) berdasarkan status financial distress pada Grup Perusahaan Keluarga 
Hasil pengujian menggunakan uji beda menunjukkan bahwa variabel Sales General and Administrative Index (SGAI) tidak ada perbedaan perlakuan atau tidak berpengaruh terhadap status Financial Distress berdasarkan Grup Perusahaan Keluarga. SGA adalah rasio perbandingan antara beban penjualan, umum, dan administrasi terhadap penjualan tahun sekarang dengan penjualan tahun sebelumnya. Jika penjualan meningkat dengan menurunkan beban operasional perusahaan, maka diindikasi adanya manipulasi untuk memperoleh laba tiap tahun. Apabila penjualan menurun dan beban operasional meningkat maka dapat diindikasi distress.

Hasil penelitian ini tidak sependapat dengan teori dasar Beneish M-Score yang dikembangkan oleh Profesor Messod Beneish bahwa Beneish MScore adalah sebuah metode membantu mengungkap kemungkinan distress pada perusahaan terhadap biaya penjualan, umum dan administrasi yang dicatat dalam laporan keuangan perusahaan (Christy \& Stephanus, 2018) namun didukung oleh penelitian yang dilakukan oleh Kusuma (2017) dan Hantono (2018).

\section{Perbedaan Leverage Index (LVGI) berdasarkan status financial distress pada Grup Perusahaan Keluarga}

Hasil pengujian menggunakan uji beda menunjukkan bahwa variabel Leverage Index (LVGI) tidak ada perbedaan perlakuan atau tidak berpengaruh terhadap status Financial Distress berdasarkan Grup Perusahaan Keluarga. LVGI yang besar dapat menyebabkan nilai hutang yang ditanggung perusahaan semakin besar. Pada saat tekanan tinggi dari pihak eksternal terjadi, maka kemungkinan mengalami distress dikarenakan tidak mampu memenuhi hutangnya.

Hasil penelitian ini tidak sependapat dengan teori dasar Beneish M-Score yang dikembangkan oleh Profesor Messod Beneish bahwa Beneish MScore adalah sebuah metode membantu mengungkap kemungkinan distress pada perusahaan terhadap kewajiban/hutang yang dicatat dalam laporan keuangan perusahaan (Christy \& Stephanus, 2018), namun didukung oleh penelitian yang dilakukan oleh Hantono, (2018).

\section{Perbedaan Total Accruals to Total Assets Index (TATA) berdasarkan status financial distress pada Grup Perusahaan Keluarga}

Hasil pengujian menggunakan uji beda menunjukkan bahwa variabel Total Accruals to
Total Assets Index (TATA) ada perbedaan perlakuan atau berpengaruh terhadap status financial distress berdasarkan Grup Perusahaan Keluarga. Komponen TATA adalah rasio perkiraan kas mendasari pendapatan yang dilaporkan dan juga perkiraan accruals positif yang lebih tinggi dikaitkan kemungkinan terjadinya distress.

Hasil penelitian ini sependapat dengan teori dasar Beneish M-Score yang dikembangkan oleh Profesor Messod Beneish bahwa Beneish M-Score adalah sebuah metode membantu mengungkap kemungkinan distress pada perusahaan terhadap total aset yang dicatat dalam laporan keuangan perusahaan (Christy \& Stephanus, 2018), namun tidak didukung oleh penelitian yang dilakukan oleh Hantono, (2018).

\section{Kesimpulan, Keterbatasan, dan Implikasi Hasil Penelitian}

Berdasarkan hasil pengujian dalam penelitian ini terhadap 8 (delapan) komponen Beneish Model dengan menggunakan uji beda, dapat disimpulkan sebagai berikut :

1. Variabel Days Sales in Receivable Index (DSRI) tidak ada perbedaan perlakuan komponen Beneish Model berdasarkan status Financial Distress pada Grup Perusahaan.

2. Variabel Gross Margin Index (GMI) ada perbedaan perlakuan komponen Beneish Model berdasarkan status Financial Distress pada Grup Perusahaan.

3. Variabel Asset Quality Index (AQI) ada perbedaan perlakuan komponen Beneish Model berdasarkan status Financial Distress pada Grup Perusahaan.

4. Variabel Sales Growth Index (SGI) tidak ada perbedaan perlakuan komponen Beneish Model berdasarkan status Financial Distress pada Grup Perusahaan.

5. Variabel Depreciation Index (DEPI) ada perbedaan perlakuan komponen Beneish Model berdasarkan status Financial Distress pada Grup Perusahaan.

6. Variabel Sales General and Administrative Index (SGAI) tidak ada perbedaan perlakuan komponen Beneish Model berdasarkan status Financial Distress pada Grup Perusahaan.

7. Variabel Leverage Index (LVGI) tidak ada perbedaan perlakuan komponen Beneish Model berdasarkan status Financial Distress pada Grup Perusahaan.

8. Variabel Total Accruals to Total Assets Index (TATA) ada perbedaan perlakuan komponen 
Beneish Model berdasarkan status Financial Distress pada Grup Perusahaan.

Dapat disimpulkan bahwa pengukuran prediksi status financial distress dengan menggunakan beneish model pada Grup perusahaan keluarga didapat hasil ada 4 komponen yang ada perbedaan berdasarkan status financial distress pada Grup perusahaan yaitu Gross Margin Index (GMI), Variabel Asset Quality Index (AQI), Depreciation Index (DEPI), dan Total Accruals to Total Assets Index (TATA).

\section{Daftar Pustaka}

Anggarini, T. (2010). Pengaruh Karakteristik Komite Audit Terhadap Financial Distress (Studi Empiris pada Perusahaan yang Terdaftar di Bursa Efek Indonesia). UniverstasDiponegoro, Semarang.

Christy, I. M., Sugito, \& Hoyyi, A. (2015). Penerapan Formula Beneish M-Score Dan Analisis Diskriminasi Linier Untuk Klasifikasi Perusahaan Manipulator dan Non Manipulator (Studi Kasus Di Bursa Efek Indonesia Tahun 2013). Jurnal Gaussian, 4(2), 287-293.

Christy, Y. E., \& Stephanus, D. S. (2018). Pendeteksian kecurangan laporan keuangan dengan Beneish M-score pada perusahaan perbankan terbuka. Jurnal Akuntansi Bisnis, 16(2), 148.

Darmawan, A. Z. (2016). Analisis Beneish Ratio Index Untuk Mendeteksi Kecurangan Laporan Keuangan. Jurnal Profita: Kajian Ilmu Akuntansi, 4(6).

Sanjaya, H. Ghozali, I.(2016). Aplikasi Analisis Multivariete dengan Program IBM SPSS 23 (VIII). Semarang: Badan Penerbit Universitas Diponegoro.

Hantono. (2018). Deteksi Financial Statement Fraud Melalui Model Beneish Pada Perusahaan BUMB. Jurnal Manajemen Bisnis Dan Inovasi, 5(3), 135-150.

Hapsari, E. I. (2012). Kekuatan Rasio Keuangan dalam Memprediksi Kondisi Financial Distress Perusahaan Manufaktur di BEI. Jurnal Dinamika Manajemen, 3(2), 101-109.
Hariri, Pradana, A. W. S., \& Widjajanti, S. L. (2017). Predicting Financial Statement Corporate Fraud: Beneish M-Score Model. Jurnal Ilmiah Bidang Akuntansi Dan Manajemen (JEMA), 14(2), 93100.

Hidayat, M. A., \& Meiranto, W. (2014). Prediksi financial distress perusahaan manufaktur di Indonesia (studi empiris pada perusahaan manufaktur yang terdaftar di Bursa Efek Indonesia periode 2008-2012) (Doctoral dissertation, Fakultas Ekonomika dan Bisnis).

Iswanaji, C. (2018). Mendeteksi kecurangan laporan keuangan menggunakan beneish ratio index pada Pabrik Cambric Yogyakarta. Jurnal Reviu Akuntansi dan Keuangan, 8(1), 25-34.

Prehantika, F. K. I. (2016). Deteksi financial statement fraud dengan model beneish $\mathrm{m}$ score. Jurnal Akuntansi AKUNESA, 5(1), 1-22.

Kristanti, F. T., Rahayu, S., \& Huda, A. N. (2016). The determinant of financial distress on Indonesian family firm. Procedia-Social and Behavioral Sciences, 219, 440-447. https://doi.org/10.1016/j.sbspro.2016.05.018.

Srengga, R. (2012). Analisis rasio keuangan untuk memprediksi kondisi financial distress perusahaan manufaktur yang terdaftar di bursa efek indonesia.. Jurnal Akuntansi, 139-154.

Oktaviandri, A., \& Firli Aldilla Iradianty, A. (2017). Analisis Prediksi Kebangkrutan Dengan Model Altman, Springate, Ohlson, dan Grover Pada Perusahaan Di Sektor Pertanian Bursa Efek Indonesia Periode 2011 â 2015. Majalah Ilmiah UNIKOM, 15(1), 71-78.

Permana, R. K., Ahmar, N., \& Djadang, S. (2017). Prediksi Financial Distress pada Perusahaan Manufaktur di Bursa Efek Indonesia. Esensi: Jurnal Bisnis dan Manajemen, 7(2), 149-166.

Prihanthini, N. M. E. D., \& Sari, M. M. R. (2013). Prediksi Kebangkrutan Dengan Model Grover, Altman Z-Score, Springate Dan Zmijewski Pada Perusahaan Food And Beverage Di Bursa Efek Indonesia. E-jurnal akuntansi Universitas Udayana, 5(2), 417-435.

Rise, N. E. (2017). Pendeteksian Financial Statement Fraud Menggunakan Beneish Ratio 
Index (Studi pada Perusahaan yang Terdaftar di Bursa Efek Indonesia).

Simanjuntak, A. (2010). Prinsip-Prinsip Manajemen Bisnis Keluarga (Family Business) Dikaitkan Dengan Kedudukan Mandiri Perseroan Terbatas (PT). Jurnal Manajemen dan Kewirausahaan, 12(2), 113-120.

Sugiyono, D. R. (2001). Statistik Non Parametris untuk Penelitian. Bandung: Alfabeta.
Tukan, T. N. S. S. (2018). Analisis Faktor Penjelas Financial Distress pada Perusahaan Manufaktur di Bursa Efek Indonesia. Jurnal Manajemen Bisnis Indonesia (JMBI), 7(5), 501-511.

Zakkiyah, U. Z. (2014). Analisis Penggunaan Model Zmijewski (X-Score) dan Altman (Z-Score) untuk Memprediksi Potensi Kebangkrutan (Studi Pada Perusahaan Tekstil dan Garmen yang Terdaftar di (BEI) Bursa Efek Indonesia Periode 2009-2012). Jurnal Administrasi Bisnis, 12(2), 1-10. 